\title{
Increasing Teachers' Ability Using Zoom Meeting Applications In The Distance Learning Process Through Collaborative Assistance In Sd Negeri Bendo Kapanewon Samigaluh Kulon Progo Academic Year 2020/2021
}

\author{
Francisca Saminem $^{\text {a,* }}$ \\ a SD Negeri Bendo Kapanewon Samigaluh Kulon Progo \\ *Corresponding author: saminemfrancisca@gmail.com
}

Received: August 11, 2021; Accepted: October 4, 2021; Published: October 15, 2021

\begin{abstract}
This research was motivated by the regulation of the Ministry of Education and culture regarding the implementation of education during the Covid-19 pandemic which required distance learning using online learning media. Online learning is a learning method that aims to improve the ability of teachers to use the Zoom Meeting application program at SD Negeri Bendo Kapanewon, Samigaluh Kulon Progo during the Covid-19 pandemic. This research is a school action research to improve the ability of school principals in managing learning leadership through collaborative mentoring. The subjects in this study were SD Negeri Bendo teachers, totaling 8 teachers consisting of 6 classroom teachers and 2 subject teachers. The purpose of this study was to improve the ability of teachers in implementing distance learning by using the Zoom Maeting application for Bendo Elementary School teachers through collaborative mentoring activities. The results of preliminary observations show that the ability of teachers at SD Bendo Kapenewon, Samigaluh, Kulon Progo, using the Zoom Meeting application is still in the "Not Good" category with a percentage reaching $87.50 \%$. The ability of teachers in the first cycle of research results obtained by research data based on the average number based on the presentation of the first cycle, the highest score was $83.72 \%$, the conversion value reached 3 , the "Good" category, while in the second cycle the average number based on the highest score percentage was $92,43 \%$, conversion value reached 4, category "Very Good". Through collaborative assistance, the principal can improve the ability of the principal in delivering the Zoom meeting application program. Collaborative mentoring cycle I observations based on the assessment of participants the average number of classes based on the presentation of the highest score of $89.58 \%$, when converted into a score it reached 4, with the "Very Good" category, while in the second cycle the average number was obtained based on the percentage the highest score is $92.71 \%$, when converted into a value of 4 , the category "Very Good", the results of the study show that there is an increase of $3.13 \%$ in the implementation of collaborative mentoring can improve the competence of the principal in delivering the Zoom meeting application program
\end{abstract}

Keywords: zoom meeting, distance learning, collaborative mentoring

\section{INTRODUCTION}

The Instruction of the Governor of the Special Region of Yogyakarta No. 2/INSTR/2021 regarding the policy of restricting community activities in the Special Region of Yogyakarta states that schools carry out online teaching and learning activities. The Covid-19 pandemic has not ended, so teachers have the task of carrying out the learning process and must adapt to applicable regulations by implementing learning from home. Schools as educational institutions play an important role in the success of the implementation of education in the era of the Covid-19 pandemic. Teachers or educators are expected to be competent and have creativity in adapting to government policies. Of course it is not easy for teachers, the implementation of learning according to the rules during this pandemic has been carried out by teachers until the end of 2020. 
Based on the results of observations made at SD Negeri Bendo Kapanewon Samigaluh, it shows that there are problems faced by teachers at SD Negeri Bendo in dealing with distance learning, namely teachers have inadequate technological mastery skills, internet networks in the area where assignments are not smooth and there is still a lack of related training. by increasing the competence of teachers in the field of Information technology.

Based on these problems, the researchers are interested in conducting research on improving the ability of teachers to use technology applications, namely zoom meetings. The use of the Zoom Meeting Application is expected to provide a breakthrough for teachers, students and parents, in overcoming the problems of learning from home. The use of the Zoom Meeting Application is very important for teachers during the distance learning process. The use of the Zoom Meeting application is an effective and interactive way that can be implemented by teachers, students and parents in distance learning in order to achieve learning objectives as expected.

Zoom Meeting is a video conferencing application developed by a company from the United States (Zoom Video Communications, Inc.). which can be used on a computer or smartphone. The Zoom application is an application that can be used by doing virtual learning. The zoom application can bring together students and educators by using videos so that the learning process can be conveyed properly [1]. This Zoom application makes it easy for every user to meet face-to-face, share information, and stay connected to each other even though it is done remotely [2].

The Covid-19 pandemic requires schools to innovate so that the learning process can run smoothly. To overcome the problems faced at SD Negeri Bendo, Kapanewon Samigaluh Kulon Progo, it is necessary to provide assistance in the form of using technology applications, one of which is the use of zoom meetings as a means that can be used in the distance learning process.

Mentoring is a community empowerment activity by placing assistants who act as facilitators, communicators and dynamists [3]. Mentoring is the provision of assistance to individuals in a sustainable and systematic manner carried out by an expert who has received special training for that, intended so that individuals can understand themselves, their environment, and can direct themselves and adapt to the environment to be able to develop his potential optimally for his own welfare and the welfare of society [4].

There are six objectives of psychological assistance and counseling, namely: a) change towards growth. In mentoring, the mentor continuously facilitates the person being accompanied to become an agent of change for himself and his environment. b) achieve a full and complete self-understanding. c) learn to communicate healthier. d) practice new, healthier behaviors. e) learn to express themselves fully and completely, through mentoring and counseling, people are helped to be able to spontaneously, creatively, and effectively express their feelings, desires and aspirations. and f) surviving, which is helping people to survive in the present, accept the situation gracefully, and reorganize their lives with new conditions [4].

\section{RESEARCH METHODS}

This type of research is School Action Research for problem solving related to change directed at increasing the ability of school principals related to learning in the pandemic era. This study aims to examine the problems accompanied by the ability of teachers in the use of distance learning and to examine the impact of treatment on teacher behavior in improving learning practices. The assessment is carried out in the form of improving the ability of teachers and trying to minimize the negative aspects of teachers who have been implementing distance learning. The place of research was carried out at SD Negeri Bendo, Kapanewon Samigaluh, Kulon Progo Regency, this area is in the Menorah Mountains.

The subjects of this study were Bendo State Elementary School teachers, totaling 8 teachers consisting of 6 classroom teachers and 2 subject teachers. The research subject has a very strategic role because the research subject is data about the observed variables. The object of research is the focus of attention and research problems. The object of research is the research target to obtain answers and solutions to problems. The object of the research is how to improve the ability of teachers in implementing distance learning with Zoom Meeting applications for Bendo Elementary School teachers through collaborative mentoring activities. The time of the research was carried out for 3 months, starting from January to April 2020.

Data were collected through observation and documentation studies. The analytical technique used in this research is descriptive quantitative data, to determine the success of the action through collaborative 
mentoring, the researcher uses a spiral model research design from Kemmis and Taggart developed by Stephen Kemmis and Robin Mc Tanggart [5] consisting of two cycles each cycle using four components of action, namely planning, action, observation and reflection in an interrelated spiral. The research plan for each cycle can be seen in Figure 1.

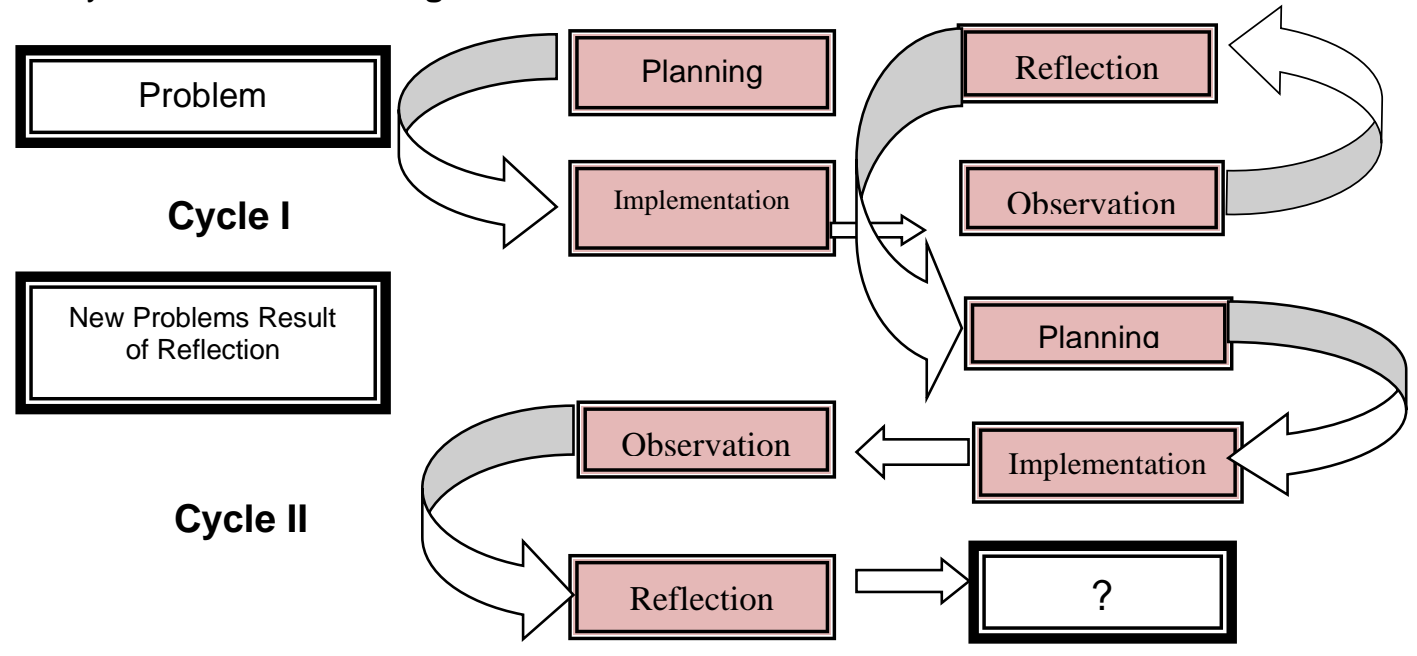

Figure 1. Action Research Design

The action plan based on the design drawing above includes: 1) The planning stage is carried out by developing an action plan based on the identification of problems in the initial observation before the research is carried out. 2) Action is what the principal as a researcher does as an effort to improve, increase or change the desired. 3) The observation stage is observing the results or impacts of the actions carried out or imposed on the teacher. 4) The reflection stage of the researcher examines, sees and considers the results or impacts of actions from various criteria.

The data collection techniques used by researchers in this classroom action research are: Documents [6]. Meanwhile, in school action research conducted by document researchers, it is the result of initial data acquisition obtained through a review of previous documents. Data collection can be done by various techniques, including the use of tests, the use of questionnaires/questionnaires, the use of the interview/interview method, the use of observation methods, documentation, etc [7].

The observations made by the researcher were assisted by colleagues to see the level of the teacher's ability to carry out the process. distance learning using zoom meetings and the implementation of collaborative mentoring. The results of observations made in the form of tables and then described to find out the results of the study. Observation sheet related to the implementation and ability of teachers to conduct zoom meetings covering 10 aspects consisting of 32 indicators, each indicator given a score of 14. As for the competence of the principal, the observation sheet includes 9 aspects consisting of 36 observed indicators, each indicator is given a minimum score $=1$ and a maximum $=4$, with the categories Unsatisfactory, Unsatisfactory, Satisfactory, and Very Satisfactory.

The data analysis technique of observational research on collaborative mentoring activities, which includes 3 aspects, 9 sub-aspects and 36 indicators for each indicator, is given a score of $1-4$, with categories: Not Good, Less Good, Good, and Very Good. While the observation data on participant activities, observation data on the implementation of distance learning which includes 10 aspects of 32 indicators, each indicator is given a score of $1-4$, using value conversion $(0 \%<X 44 \%=1 ; 45 \%<X 64$ $\%=2 ; 65 \%<X 84 \%=3$; and $85 \%<X 100 \%=4)$. The analysis uses the average of the observations, then the average results are described for each instrument. This descriptive analysis is used to describe the characteristics of the research data and answer the problems listed in the problem formulation. The descriptive analysis used in this study is the minimum score, maximum score, average, and percentage with the formula:

$$
\text { Final Score }=\frac{\text { Total score }}{\text { Maximum Score }} \times 100 \%
$$


The indicators for the success of this school action research are: Improving the ability of teachers in implementing distance learning which is seen during the collaborative mentoring process, as well as from increasing the percentage of teacher participation with success criteria either (3) or in the form of a percent equal to $85 \%$ or more.

\section{RESULTS AND DISCUSSION}

Research subjects before mentoring teachers experienced difficulties in implementing distance learning, the use of learning media was only monotonous, which was only limited to the WhatsApp Group application as the only online media. Many students and parents who accompany learning activities from home find it difficult because of the lack of explanation from the teacher. The results of initial observations show that the ability of teachers to use other applications besides WhatsApp Group, and especially Zoom meetings is still very low. It is evidenced by the results of initial observations showing teachers at SD Bendo Kapenewon Samigaluh Kulon Progo from 8 teachers, 7 teachers based on observations of their ability to use ICT are still "less good" in using the Zoom Cloud Meeting application, reaching $87.50 \%$, while there is still 1 teacher who already understands about using the Zoom Cloud Meeting application. If the presentation reaches $12.50 \%$, the fact is very concerning because teachers should have understood various applications for the implementation of distance learning, to overcome this problem the principal took action to conduct school action research with the title: "Improving Teacher Ability Using the Distance Learning Zoom Meeting Application Through Collaborative Mentoring at SD Negeri Bendo Kapanewon Samigaluh Kulon Progo for the 2020/2021 Academic Year".

Cycles I and II of the learning process are processes in which there is interaction between students and teachers requiring reciprocal communication that takes place in an educative situation in order to achieve learning objectives during the COVID-19 pandemic, of course very different from learning such as face-to-face teachers with participants. educate. However, in pandemic conditions, learning is carried out online using a communication media smartphone to deliver materials and assignments through the Zoom meeting application. The school principal takes collaborative mentoring steps with material to increase the ability of teachers in the use of the Zoom meeting application, the results of which are obtained based on the observations of researchers with collaborative data cycles I and II as follows:

1. The ability of participants to use the Zoom meeting application program.

Based on the results of research conducted by researchers with collaborators on the use of the Zoom meeting application program, the results of research observations related to the abilities of participants (teachers) can be seen in Table 1.

Table 1. The ability of participants to use the Zoom Meeting Cycle I and II application program at SD Negeri Bendo Kapanewon Samigaluh Kulon Progo for the 2020/2021 Academic Year

\begin{tabular}{llcccccccc}
\hline & \multirow{8}{*}{ No. } & \multirow{8}{*}{ Cycle } & \multicolumn{1}{c}{ Total Grade Average Score (\%) } \\
\cline { 3 - 10 } & & $\mathbf{1}^{\text {st }}$ & $\mathbf{2}^{\text {nd }}$ & $\mathbf{3}^{\text {rd }}$ & $\mathbf{4}^{\text {th }}$ & $\mathbf{5}^{\text {th }}$ & $\mathbf{6}^{\text {th }}$ & \multirow{2}{*}{ PJOK } & \multirow{2}{*}{ PAI } \\
\hline A & Cycle I & 71,69 & 73,81 & 74,52 & 72,15 & 73,55 & 83,72 & 71,07 & 71,36 \\
B & Cycle II & 88,16 & 88,36 & 89,34 & 86,32 & 88,17 & 92,43 & 85,70 & 86,77 \\
\hline
\end{tabular}

Based on the results of the study in the table above, it shows the average number of classes based on the presentation of the first cycle, the highest score is $83.72 \%$, the conversion value is 3 , the category "Good", while in the second cycle the average number of classes based on the highest score percentage is 92.43 . \%, the conversion value reached 4, the "Very Good" category, the results showed that there was an increase in the collaborative assistance of participants in using the Zoom meeting application program, the same thing was stated first by: Sultan Hadi Prabowo with the title The Role of Collaborative Mentoring in Online Learning in the Middle Covid-19 pandemic. This research has similarities in how to overcome the distance between educators and students with the implementation of distance learning.

2. Implementation of Collaborative Assistance by resource persons using the Zoom Meeting application in Distance Learning. 
The results of research related to the implementation of collaborative mentoring carried out by researchers showed significant developments, and had a positive impact on the ability of teachers to use the Zoom Meeting application. From observing the problems of teachers in the implementation of online classes (online) learning to students during the learning process, teachers experienced several changes in their ability to use the Zoom Meeting application, which previously were not familiar with until now they were skilled at using the application. To find out the results of the study can be seen in Table 2.

Table 2. Ability of Resource Persons in Delivering Zoom Meeting Applications Through Collaborative Mentoring Cycle II meeting 2 at SD Negeri Bendo Kapanewon Samigaluh Kulon Progo Academic Year 2020/2021

\begin{tabular}{cccccccccc}
\hline & \multirow{8}{*}{ No. } & Cycle & \multicolumn{8}{c}{ Total Grade Average Score (\%) } \\
\cline { 3 - 10 } & & $\mathbf{1}^{\text {st }}$ & $\mathbf{2}^{\text {nd }}$ & $\mathbf{3}^{\text {rd }}$ & $\mathbf{4}^{\text {th }}$ & $\mathbf{5}^{\text {th }}$ & $\mathbf{6}^{\text {th }}$ & \multirow{2}{*}{ PJOK } & \multirow{2}{*}{ PAI } \\
\hline 1 & Cycle I & 84,38 & 84,03 & 83,68 & 78,82 & 81,25 & 89,58 & 81,25 & 81,60 \\
2 & Cycle II & 89,93 & 88,54 & 88,89 & 86,46 & 88,54 & 92,71 & 88,54 & 87,50 \\
\hline
\end{tabular}

The results of the research related to the implementation of mentoring obtained research data based on the average number of classes based on the presentation of the first cycle, the highest score was $89.58 \%$, the conversion value was 4 , the "Very Good" category, while in the second cycle the average number of classes was obtained based on the highest score percentage. 92.71\%, conversion value of 4, category "Very Good", the results of the study show that there is an increase of 3.13\% proving that the implementation of collaborative mentoring can improve the competence of principals in delivering the Zoom meeting application program. Collaboration as a thought process in which the parties involved look at the different aspects of a problem and find solutions to these differences and the limitations of their views on what can be done [8]. Based on the theory above, the collaborative mentoring process in research shows that strategies for solving learning problems in the Covid-19 era are through appropriate strategies and methods to improve teacher skills using the Zoom meeting application.

The online learning process (online) uses the Zoom meeting application program via a smartphone or laptop. Online learning is learning that is done without face-to-face but through available platforms. Online learning is a system of teaching and learning processes that are carried out without having to meet face-to-face between educators and students [9]. The results of the observations that the researchers did, when the practice of the learning process was carried out online (online) through the planning, implementation and evaluation stages. where at first the teacher formed an online group through one of the communication media, namely Zoom meeting for learning at SD Negeri Bendo Kapanewon Samigaluh Kulon Progo then implemented into teaching and learning activities.

\section{CONCLUSION}

The results of initial observations show that the ability of teachers to use media or other applications other than WhatsApp Group, and especially Zoom Cloud Meetings is still very low. Initial observations showed teachers at SD Bendo Kapenewon Samigaluh Kulon Progo from 8 teachers, 7 teachers based on observations of their ability to use ICT were still "Not Good" using the Zoom Cloud Meeting application, the findings when presented reached $87.50 \%$, There was 1 teacher who used the Zoom application Cloud Meeting, when presented reaches $12.50 \%$. Through Collaborative Mentoring activities, teachers can improve the ability of teachers to use the Zoom meeting application in distance learning during the Covid19 pandemic, at SD Negeri Bendo Kapanewon, Samigaluh, Kulon Progo in 2020/2021. Marked by an increase in the ability of teachers in the first cycle, the results of the study showed that the average number of classes based on the presentation of the first cycle, the highest score was $83.72 \%$ with category "Good", while in the second cycle, the average number of classes was obtained based on the highest score percentage is $92.43 \%$, with category "Very Good", the results of the study show that there is an increase in the ability of participants to use the Zoom meeting application. Through collaborative mentoring activities can improve the ability of school principals in delivering the Zoom meeting application program. Each cycle, 
in which the first cycle of observations based on the assessment of the participants, the average number of classes in the first cycle, the highest score of $89.58 \%$, the conversion value reached 4 , the category "Very Good", while in the second cycle the average number of classes based on the percentage of the highest score was $92,71 \%$, the conversion value reached 4, the category "Very Good", the results showed an increase of $3.13 \%$ proving that the implementation of collaborative mentoring can improve the competence of principals in delivering the Zoom meeting application program.

\section{REFERENCES}

1. M. Yuliani, Pembelajaran daring untuk pendidikan: Teori dan penerapan. (Yayasan Kita Menulis, Medan, 2020)

2. Ahamdi and A.M. Ilmiani, Metode pembelajaran Bahasa Arab: Konvesional Hingga Era Digital, (Ruas Media, Yogyakarta, 2020).

3. R. Primahendra. Pedoman Pendampingan Untuk Pemberdayaan Masyarakat (Dinkesos, Jakarta, 2002)

4. T.S. Wiryasaputra. Ready To Care: Pendamping dan Konseling Psikoterapi. (Galang Press, Yogyakarta, 2006)

5. Basrowi. Evaluasi Belajar Berbasis Kinerja. (Rineka Cipta, Bandung, 2012)

6. B. Burhan. Penelitian Kualitatif. (Kencana. Jakarta, 2011)

7. A, Suharsimi. Prosedur Penelitian Suatu Pendekatan Praktek, (Rineka Cipta, Jakarta, 2005)

8. Barbara, G. Collaborating: finding Common Ground for Multiparty Problems. (Jossey-Bass Publishers, San Fransisco, 1989)

9. Ardiansyah. Eksplorasi Pola Komunikasi dalam Diskusi Menggunakan Moddle pada Perkuliahan Simulasi Pembelajaran Kimia. (Universitas Pendidikan Indonesia, Bandung, 2013) 